\title{
The Influence of Bosnian Islam on the Identity of Slovenian Muslims
}

\author{
Vpliv bosanskega islama na identiteto \\ slovenskih muslimanov
}

\begin{abstract}
The article focuses on the identity of Slovenian Muslims. The Population Census in Slovenia shows that the majority of Slovenian Muslims by ethnicity are defined as Bosniaks, Muslims or Bosnians. All three national classifications apply to migrants from Bosnia and Herzegovina (B-H). In recent times, religion, beside nationalism and culture, has had a significant influence on the formation of the identity of Muslims in both B-H and in Slovenia. The primary characteristic of the population of $B-H$ is its heterogeneity. Thus, religious identity has always been evenly tied to its national and political identity. However, we must not ignore the fact that Bosnian Islam has always been different from Islam on other continents, which is especially evident in the ceremonials and everyday manners. The influence of religion is derived from the reality of religious practices that individuals have adapted to their cultural identity. In this discussion, we will attempt to identify the connections that relate to Slovene Islam in Muslim religious practice.
\end{abstract}

Key words: Islamic identity, Bosnian Islam, religious practice, Slovenian Muslims

Povzetek: Prispevek se osredotoča na identiteto slovenskih muslimanov. Popis prebivalstva v Sloveniji kaže na to, da se večina slovenskih muslimanov po narodnosti opredeljuje za Bošnjake, Muslimane in Bosance. Vse tri narodnostne opredelitve se nanašajo na migrante iz Bosne in Hercegovine (BiH). Na oblikovanje identitete muslimanov v BiH in posledično tudi v Sloveniji je imela poleg nacionalizma in kulture velik vpliv tudi religija. Glavna specifika $\mathrm{BiH}$ je njena vsestranska heterogenost. Tako je bila religijska identiteta vedno najtesneje izenačena z narodnostno in politično. A ne smemo prezreti dejstva, da je bosanski islam od nekdaj nekoliko drugačen od islama na drugih celinah, kar se še posebej kaže v obrednem in vsakdanjem življenju. $\mathrm{V}$ razpravi bomo poskušali pokazati, kako sta »bosanski« islam in verska praksa muslimanov v $\mathrm{BiH}$ vplivala na versko prakso slovenskih muslimanov.

Ključne besede: islamska identiteta, bosanski islam, religijska praksa, slovenski muslimani 


\section{Islamic Religious Identity}

Khoury $(2008,35)$ describes different Islamic identities. He mentions the concepts of maximum and optimal Islamic identity. A person living under the first concept lives by the rules of Sharia and religious law, thus incorporating religion into all areas of their life. In contrast, the latter concept can only be achieved in countries with a majority Muslim population, where Sharia has national-level validity. Optimal Islamic identity is achieved if a Muslim does not live in an Islamic state, but the state nevertheless ensures religious freedom. Bosnian and Slovenian Muslims have an optimal Islamic identity. ${ }^{1}$

\section{Bosnian Islam}

In 1463 , Bosnia became part of the Ottoman Empire. For a better quality of life, Bosnians began to convert to Islam. The situation changed after the occupation by the Austro-Hungarian Empire (1878). It was with great delay that the national identity of the nation began to emerge, which was firmly linked to its religious affiliation. In order to attain the loyalty of the Bosnian Muslims, at the Emperor's command, in October 1882, the supreme religious body of Ulema Majlis, the office of Reis-ul ulema, head and spiritual leader of the Bosnian Muslims, was established, thereby achieving independence from the Ottoman caliph. (Velikonja 1998, 155)

The connection with the West brought about modernism and reforms, the most important of which were school reforms, the formation of its own parties, cultural activities, and finally the translation of the Koran (1937) into Croatian language. In the era of the Socialist Federal Republic of Yugoslavia (SFRY), religious schools were closed, and the special judiciary, cultural and religious organizations and societies were abolished. At the eighth regular session of the People's Assembly of the People's Republic of B-H, on 28 September 1950, the Law on the Prohibition of Wearing

1 Interreligious dialogue is thus easier to achieve. Namely, it is much easier to talk to Muslims about Islam where they are in minority. (Osredkar 2016, 24) 
"Zara« and »Feredža ${ }^{2}$ was adopted. Nationalization of Bosnian Muslims also followed. Muslim religious life was forced to move to a private level. (Malcolm 1996, 195-196; Friedman 1996, 150)

Sociologist Esad Cimić (1966) found that of 500 respondents, 49.17\% identified themselves as religious. Muslims opted for $31.2 \%$. These included theologically convinced believers ( 2 interviewees), traditional believers (86 interviewees), and shocked/terrified believers (11 believers).

In 1987, a second analysis was made by the Institute for the Study of National Relations. Among the respondents, 37.32\% of Muslims were religious, $43.66 \%$ were non-believers, but had nothing against religion, and 6.52\% were non-believers who opposed religion. (Bakić 1994, 72)

At the start of the Bosnian war, 1,800,000 Muslims were thought to live in B-H, accounting for $45 \%$ of the population. That included $1,790,000$ Bosniaks, 5,000 Albanians and as many Roma. The war and all the unique processes that followed brought to the fore the question of contemporary Bosniak identity. According to some estimates, only half of Muslims were engaged in relatively continuous Muslim religious life before the war (Kukoč 1995, 942). The secularized half of Muslims was Muslim only in terms of culture and tradition. The number of believers increased drastically in the decade after the war, meaning that in 1998, 84.8\% of Bosniaks, $88 \%$ of Croats, and $81.6 \%$ of Serbs identified themselves as very religious or medium believers (Vrcan 2001; Velikonja 2002, 197).

\section{Religious practice of Muslims in B-H in the new millennium}

How have the events described affected the religious practices of Muslims in B-H was the question Dino Abazović wanted to explore. His survey was conducted in the second half of October and in the first half of November 2007. In one of 32 questions, more than 150 variables were divided into the following strands: National Conflict Self-Identification, Personal Beliefs, Religious Power, Experiencing God's Collaboration, Religious Belief,

2 Meaning burka. 
Vitality of Religion, Authoritarianism, Traditionalism, Ethnocentrism, Nationalism, and the Attitude toward the West. Five hundred people were interviewed, of which 51\% were women ( 255 persons) and 49\% men (245 persons).

Respondents' ages ranged from 17 to over 77, with age groups approximately evenly distributed. The largest group of respondents (15.1\%) was between 24 and 30 years old, and the smallest (4.2\%) was older than 77 years.

Most respondents (86.6\%) reside in B-H, 11.2\% in the Republic of Serbia and $2.2 \%$ in the Brčko District. Half of them live in cities, and the other half live in rural areas. Of those who are parents, most have two children (58.3\%), 14.8\% have one child, and 13.8\% have three children. The survey showed poor educational attainment, with only $11 \%$ achieving a bachelor's degree or higher. A total of 222 (40.3\%) people had completed secondary school; it is of particular concern that as many as 98 people had not completed primary school; 111 people have only completed primary education.

In this paper, we will focus only on issues related to religious practice.

A total of $55.7 \%$ of respondents described themselves as Muslims, 22.7\% among them Bosniaks, 16.8\% Bosniaks/Muslims, 3.6\% Bosnian and Herzegovinians, and $0.8 \%$ a different nationality; $0.5 \%$ did not want to answer this question.

The Islamic Community (IC) $)^{3}$ accounts for $84.6 \%$ of the respondents. The non-response was expressed by $9.5 \%, 2.8 \%$ did not know the answer to the question and $3.1 \%$ did not want to answer the question. Of these, 242 Muslims, 98 Bosniaks, 69 Bosniaks/Muslims, 10 Bosnians, three persons who do not fall into the categories, and one person who did not wish to identify themselves as belonging to the IC. There are 23 Muslims,

3 The Islamic Community of Bosnia and Herzegovina (Bosnian: Islamska zajednica Bosne i Hercegovine, $\mathrm{IZ} \mathrm{BiH}$ ) is a religious organization of Muslims in $\mathrm{B}-\mathrm{H}$. It is also recognized as the highest representative body of Muslims in the region, especially in the Serbia (Sandžak), Croatia, Slovenia, Montenegro, Hungary and Bosniak diaspora. 
4 Bosniaks, 13 Bosniaks/Muslims and eight Bosnians among non-IC members. Nine Muslims, nine Bosniaks, one Bosniak/Muslim and one non-nationalist are not certain about their affiliation with IS. Five Muslims, nine Bosniaks, one Bosniak/Muslim and one person who did not identify themselves nationally did not want to answer this question.

An interesting fact is that there are $2 \%$ fewer religious respondents than affiliated with the IC. Thus, $82.6 \%$ of the population declared themselves to be religious, $4.4 \%$ were atheistic, $7.8 \%$ were undecided, and $4.2 \%$ were unaware. However, 92.61\% acknowledge Allah, 3.3\% do not acknowledge Allah, $1.5 \%$ could not answer the question, and 2.2\% did not answer. Compared with the data of religiosity, we find that $10 \%$ believe in Allah, but are not religious, and $0.7 \%$ who professed to be atheists did not express disbelief in Allah.

On the importance of religion in everyday life, most respondents (53.1\%) answered that religion is very important in their lives. It is overwhelmingly important for 154 people (30.8\%), followed by those for whom the importance of religion plays a small role in daily life (10.1\%). It is completely irrelevant for six respondents (1.2\%), five did not answer the question, and 19 people did not want to answer.

The research revealed that $18.4 \%$ of the examinees pray five times every day, $13.3 \%$ every day but less than five times a day, $11 \%$ more than once a week, $8.8 \%$ once a week, $6.4 \%$ at least once a month and $8.6 \%$ several times a year; $14.4 \%$ pray very rarely.

During Ramadan, almost $80 \%$ of the examinees fast, of which $38.7 \%$ are fasting from sunrise to sunset. Among those who fast the whole month of Ramadan are mostly women, those who live outside of city settlements and who pray more often and more often read religious literature (Abazović 2011, 11).

Only $1.5 \%$ of the examinees have performed the Hajj. But $51.7 \%$ would do so if given the chance. In contrast, $36.2 \%$ have no intention of performing the Hajj. 63.2\% give zakat regularly, 16.6\% occasionally. 13.8\% of respondents do not perform the duty of zakat. 
Regarding reading the Koran, 4.1\% read it daily, 10.4\% a few times a week, $31.5 \%$ occasionally, $19.2 \%$ rarely, and $29.2 \%$ never. Also of interest are the answers to the question of whether they are considered religious by their parents. At most, 220 people said they were no more religious than their parents. This is followed by a group who think they are more religious than their parents (183 respondents, 57 could not answer this question, and 40 abstained).

Most respondents (40.5\%) partly trusted the IC, and 22.2\% fully trusted it, which is followed very closely by the group that trusts the IC a little (21.5\%); $8.4 \%$ do not trust it, $4.4 \%$ did not know the answer and $3.1 \%$ did not answer.

In the survey, the respondents had to identify the extent (strongly agree, overwhelmingly agree, overwhelmingly disagree, completely disagree, disagree, unanswered) to which they agree with the halal diet and dressing/ veiling of women. Most respondents, as many as $52.3 \%$, fully agree with the statement that Muslims must obey Islamic rules on food and drink. This is followed by those who overwhelmingly agree with the statement (31.7\%), followed by a group that overwhelmingly disagrees with the statement (2.2\%) and those who do not know or did not want to answer the question (4.0\%); 38.3\% examinees completely disagreed with the statement that haram food should not be sold in B-H, while 35.5\% strongly disagreed with the statement; $11.1 \%$ strongly agreed, $8.4 \%$ overwhelmingly agreed, and $6.6 \%$ did not know or did not want to answer the question.

According to Islamic rules, $43.8 \%$ of the respondents sympathize with the dress code, while slightly more than half (50.65\%) reject the concealment of women.

A total of $33.3 \%$ completely reject the need to increase the role of religion in political life, $28.2 \%$ partially reject this position, $15 \%$ overwhelmingly agree, $13 \%$ do not know the answer or did not want to share it, and the fewest of them are in complete agreement (10.5\%).

Opinions on whether the media should place greater emphasis on the value of religion are quite different: $24.9 \%$ overwhelmingly disagree, $24.3 \%$ overwhelmingly agree, and 21.9\% completely reject this view. Among those surveyed, $47.3 \%$ agree that religious leaders should not tell voters whom 
to vote for. A total of $52 \%$ of respondents believe that religion and politics should be separate.

In matters that relate to authority and tradition, we will only highlight those that seem most interesting to us about religious practice. We will emphasize the wife's obedience to her husband, her brother's responsibility for her sister's honour, her sexuality before marriage, and her views on abortion.

The statement "A wife must listen to her husband « is perfectly acceptable for $33.8 \%$. Most respondents partially agree with the statement (44.2\%), followed by those who disagree partially (10.4\%), who do not agree (5\%), who disagree completely (4.7\%); 1.9\% of respondents did not answer. The claim that the brother is responsible for the honour of his sister is (partly) agreed to by more than half of the respondents.

The results of the statement »There is nothing wrong with pre-marital intercourse are interesting. Most respondents (26.1\%) partially agree with the statement, while $23.3 \%$ completely reject the claim, $16.4 \%$ fully acknowledge sexual intercourse before marriage, and $16.7 \%$ partially disagree. $5.8 \%$ of respondents did not want to answer the question, and (11.7\%) chose the »I don't know« category.

The survey found that the issues regarding the permissibility of abortion were rather divided. Abortion is completely rejected by $18.7 \%$ of the respondents, while fully supported by $18.5 \%$. At most, $28.4 \%$ of the respondents partially supported abortion, $14.9 \%$ could not state their opinion, and $6.3 \%$ of the respondents refused to answer the question.

\section{Muslims in the Republic of Slovenia}

Islam is the world's second largest religion. According to the results of the Religious, Linguistic and Ethnic Composition of the Population of Slovenia (2002), the Islamic Community in the Republic of Slovenia is also in second place. The 2002 census showed that 47,488 Muslims live in Slovenia, which is $2.4 \%$ of the total Slovenian population. A minority of Muslims immigrated to Slovenia during the Turkish invasions, when some Slovenian people were forced to embrace the Islamic faith. The second phase of immigration 
(mainly from Bosnia) occurred after the Austro-Hungarian occupation of Bosnia in 1878. According to the 1921 census, most Muslims residing in the territory of the present-day Republic of Slovenia lived in Ljubljana, Maribor, and Murska Sobota (Šircelj 2003, 69). Also, for Muslims who, during the Yugoslav (SFRY) era, immigrated to Slovenia for labour in industry, Slovenia was desirable because of its strategic location near the West and its rapid economic growth (119).

The number of Muslims, however, increased significantly during the Yugoslav (SFRY) era and after its collapse (Simoniti 1990; Komac 2007). The 2002 census indicates that most Muslims by nationality identified as Bosniaks (19,923), followed by Muslims (9,238), Bosnians $(5,724)$, Albanians (5,237), Slovenes $(2,804)$, undefined $(2,316)$, and Macedonians (507). Pasić (2006) points out that the term »Muslim« was used for Muslims in B-H and Bosniaks were also identified with the term »Muslims«. In this definition, we must pay attention to the correlation between religion and nationality, which is mainly influenced by three factors: freedom of expression of nationality, subjective perception of the national category, and current socio-political circumstances. Since censuses no longer provide definitions (many have roots from two or even more nations), when - in regards of nationality - asked about how broadly the concept of a nation is linked beyond a narrow-minded nationalist ideology, people are defined as they understand the issue. Furthermore, some parents want to convey to their children the different identities of both of their origins. (Lavić 2018, 137)

The number of Muslims in Slovenia was increasing in the Yugoslav (SFRY) era. However, in those times they were never regarded as members of Islamic culture and religion but were viewed as workers from other republics of Yugoslavia (Kalčić 2007, 111-112). All this was probably influenced by their low levels of religious observance and the decrees of the communist regime.

It is worth mentioning that according to the 2002 census, no people of Islamic religion lived in 23 of Slovenia's 193 municipalities, less than five people of Islamic religion lived in 40 municipalities, less than 1\% in 62 municipalities, 13 from 2 to less than $4 \%$, in 5 municipalities from 4 to less than 5\% and in 8 municipalities more than 5\%. Many Muslims live in the 
following Slovene municipalities: Ljubljana, Jesenice, Velenje, Maribor, Koper, Celje, Kamnik and Trbovlje (Pasić 2005, 107).

According to the 2002 census, the Bosnian language was used by 31,449 people (SURS 2003, 7). This was certainly influenced by the fact that the Bosnian language became the official language of the Federation of B-H.

According to Article 7 of the Constitution of the Republic of Slovenia (RS), there is a separation between the state and religion in Slovenia, which means that no religion is the primary one and that all religions can operate freely. Today Islam represents the second largest religion in Slovenia. In January 2019, three Islamic organizations are registered in the Register of Churches and Other Religious Communities, the most numerous being the Islamska skupnost $v$ RS, which consists of seventeen committees. Other communities are Slovenska muslimanska skupnost and the Slovenska islamska skupnost milosti. In addition to the religious communities, the Society for the Društvo za promocijo islamske kulture Resnica Haq in Eliman and the Shiite (world) sect of Ahmadyya are also active.

Islamska skupnost RS has been operating under the Islamic Community of B-H since 12 September 1967. The first organized gathering of Muslims occurred in Slovenia five years earlier (Pasić 2005, 103). In 1994, a meshihat ${ }^{4}$ was established in Ljubljana. Twelve new jemets were organized between 1991 and 1995. Under the auspices of the Islamska skupnost RS, a parliament ${ }^{5}$ also operates and is provided by the mufti. ${ }^{6}$ At the local level, Muslims are represented by imams who are under the mufti's authority. By recognizing the Sarajevo religion, the Slovenian Islamic Community retained a spiritual, as well as a political union with Bosnia. For this reason, it undoubtedly holds that the Sarajevo Islamic Religion plays an essential role in the constitution of the Islamska skupnost $v$ RS and that, in institutional terms, the Islamska skupnost v RS is in fact Bosniak (Kalčić 2007, 56-57).

\footnotetext{
4 Mesihat: the executive body of the Islamic Community in the Republic of Slovenia (Kalčić 2007, 280).

5 Sabor: the legislative body of the Islamic Community (Kaličić 2007, 57).

6 Since 2005, the mufti is Dr. Nedzad Grabus.
} 
The Freedom of Religion Act gives religious communities the power to make their own decisions about their organization. According to the law, Muslim religious communities registered in Slovenia are also free, which means that they form legally competent authorities, internal organization, religious employees, rights and duties of their members, and associate and participate in inter-confessional forms of organization established in the Republic of Slovenia. Slovenian Muslims belong to the Hanafi Law School. This means that Slovenian Muslims, especially as regards civil law, are subject to the legal system in force in Slovenia, and Sharia law is only adhered to in the liturgy. (Osredkar 2011)

For Muslims, however, the religious practice is not only narrowed down to liturgical life but is closely linked to family law. The reflections of Bosnian Islam on Muslims in the Republic of Slovenia are reflected in both areas, but somewhat more strongly in tradition and thus family life. We have seen that the liturgical practice of Muslims in B-H is a bit lukewarm. Namely, Bosnian Islam is not as strict as Arabic Islam, as traces of secularization and modernization are reflected in it. Thus, few do the five-times-daily prayers. Some of them perform zakat duties in Slovenia, others in B-H, while others also omit them. There is a slightly higher percentage of those who fast during Ramadan, with few adhering to fasting in the full sense of the word. We must also understand the fact that in recent years the fasting period has come in the summer months, and many Muslims in the Republic of Slovenia are engaged in heavy physical work, meaning that the exclusion from fasting is justified. Every year, a few Muslims go to the Hajj.

Islam, at its core, does not recognize the translations of the Koran. However, Bosniaks received a translation into Croatian in 1938, and Slovene Muslims did in the Slovene language in 2005. The translation is critical, since most Muslims do not understand or speak Arabic. Slovenian law prohibits confessional instruction in public educational institutions. This is why religious instruction takes place on weekends. It is performed by all the mosques of the different communities. Religious education is given to children within their community, in mekteb. Slovenia does not have a madrasa, which is why Slovenian Muslims go to study abroad. Slovenian Muslims do not yet have a mosque though one is under construction, and they hope that prayers will start there at the beginning of 2020. 
Most Muslim families celebrate Muslim holidays, but because they are held several times during the week and because Islamic holidays are not working-free days in Slovenia, Muslim believers are forced to take leave. Not many of them leave for their native Bosnia during the holidays, where the festive atmosphere is much more present than in Slovenia.

Some Muslim women in Slovenia conceal themselves, predominantly younger ones, reveals Kalčić (2007, 160-184), adding that most of them covered themselves at the turn of the twenty-first century. Women whose mothers and grandmothers did not cover also began to cover themselves, but it was an individual decision. Most Bosniaks who practice Islam cover themselves only occasionally (prayer time, various religious occasions [weddings, holidays], religious education). However, we must point out that not all veiled women are Bosnian women, but are also Albanians and Muslims from African and Arab countries.

One of the precepts of Islam is the halal diet. Most Muslims in Slovenia do not adhere to it, but members of the Society tend to do so. They consume more alcohol than eat pork products. There are some companies in Slovenia (Argeta, Droga Kolinska, Perutnina Ptuj) that produce halal products. Some Slovenian Muslims shop for halal products in neighbouring Austria but these can also be purchased at the E. Leclerc store in Ljubljana. Some halal products are used only during Ramadan.

Muslims in Slovenia can opt for a religious wedding in addition to a civil and religious funeral. Most Muslims do so. There are examples of arranged marriages and polygamous relationships, but they are very rare. There are currently two Islamic cemeteries in Slovenia, in Ljubljana and Jesenice.

\section{Conclusion}

It can be said that Islam in Slovenia is predominantly Bosnian, popular Islam. Slovenian Muslims may be a little more secularized, which is influenced, on the one hand, by the general secularization of the Slovenian nation and, on the other, by the assimilation of certain Muslims. The least secularized are members of the Društvo za promocijo islamske kulture Resnica Hak in El-iman and members of Islamska skupnost milosti. 
Believers of religions may move towards the pole of the absolute or the pole of the absent, and with that they may act either fundamentally, exclusively, or even violently, or dialogically, inclusively, peacefully (Ocvirk 2016, 45). Nevertheless, we can talk about the identity of Slovene Muslims, since the younger generations have been born in Slovenia, Slovene is their first language, and most of them state that they do not want to leave Slovenia (Deklava and Razpotnik 2002). Among Muslims in Slovenia, in addition to Bosniaks, Bosnians, Muslims, Albanians and immigrants from African and Arab countries, we also find Slovenes. All Slovenians are also Europeans, hence we do not have to deny Islam as part of Europe and Muslims as equal inhabitants of the old continent.

\section{Abbreviations}

B-H Bosnia and Herzegovina

BiH Bosna in Hercegovina

IC Islamic Community

RS Republic of Slovenia

SFRY Socialist Federal Republic of Yugoslavia

\section{Bibliography}

Abazović, Dino. 2011. Bosnian Muslims at the Begining of New Millenia. 18 and 19 November https://www.akademie-rs. de/fileadmin/user_upload/ download_ archive/interreligioeser-dialog/111118 abazovic_bosnian-muslims.pdf. (21 ${ }^{\text {st }}$ August 2019).

Bakić, Ibrahim. 1994. Nacija i religija. Sarajevo: Bosnia Public.

Cimić, Esad. 1966. Socijalističko društvo $i$ religija. Ispitivanje odnosa izmedu samoupravljanja i procesa prevladavanja tradicionalne religije. Sarajevo Svjetlost.

Deklava, Bojan and Špela Razpotnik. 2002. Čefurji so bili rojeni tu: življenje mladih priseljencev druge generacije $v$ Ljubljani. Ljubljana: Pedagoška fakulteta: Inštitut za kriminologijo pri Pravni fakulteti.
Friedman, Francine. 1996. The Bosnian Muslims: Denial of a Nation. Boulder: Westview Press.

Kalčić, Špela. 2007. "Nisem jaz Barbika." Oblačilne prakse, islam in identitetni procesi med Bošnjaki v Sloveniji. Ljubljana: Filozofska fakulteta, Oddelek za etnologijo in kulturno antropologijo.

Khoury, Adel Theodor. 2008. Religija in kulturna identiteta: Primer islama v Evropi. In: Dean Komel in Mira Miladinović, ed. Obrazi Evrope. Evropa, svet in humanost v 21. stoletju: dialog med kultirami. Zbornik mednarodne konference $z$ dne 10.-12. aprila 2008, 31-40. Ljubljana: Inštitut Nove revije, Zavod za humanistiko. 
Komac, Miran. 2007. Varstvo "novih«narodnih skupnosti v Sloveniji. In: Priseljenci: Študije o priseljevanju in vključevanju v slovensko družbo, 35 65. Ljubljana: Inštitut za narodnostna vprašanja.

Kukoč, Mislav. 1995. Konfesije i postkomunistički sukob civilizacija. Društvena istraživanja 6, 937-947.

Lavić, Senadin. 2018. Bosna in Bošnjaki v kontekstu protibošnjaštva. In: Nedžad Grabus, ed. Stoletje islamske skupnosti na Slovenskem: sto let džamije v Logu pod Mangartom: zbornik strokovnih prispevkov, 105-12. Ljubljana: Kulturno-izobraževalni zavod Averroes.

Malcolm, Noel. 1996. Bosnia. A Short History. London: Papermac.

Ocvirk, Karl Drago. 2016. Razpetost religij med možnostma mirotvornega in nasilnega delovanja. Edinost in dialog 71 , $27-47$.

Osredkar, Mari Jože. 2011. Verska integracija muslimanov v Sloveniji. In: Soočenje z demografskimi izidi v Evropi: zbornik 14. mednarodne multikonference Informacijska družba - IS 2011, 10.-11. oktober 2011, 90-95. Ljubljana: Inštitut Jožef Štefan.

- - -. 2016. Krščanski dialog v medčloveških odnosih. Edinost in dialog 71, 13-25.
Pašić, Ahmed. 2005. Islam in muslimaniv Sloveniji. Tržič: Učila International.

- - -. 2006. Islam in moderni Zahod. Integracija Islamske skupnostiv moderne zahodne družbe. Kranj: Gorenjski glas, d. o. o.

Simoniti, Vasko. 1990. Turki so v deželi že: turški vpadi na slovensko ozemlje $v 15$. in 16. stoletju. Celje: Mohorjeva družba.

Statistični urad Republike Slovenije. 2003. Statistične informacije, št. 93/2003. Statistični urad Republike Slovenije. (internet source)

Šircelj, Milovoja. 2003. Verska, jezikovna in narodna sestava prebivalstva Slovenije: Popisi 1921-2002. Ljubljana: Statistični urad Republike Slovenije.

Velikonja, Mitja. 1998. Bosanski religijski mozaiki: religije in nacionalne mitologije $v$ zgodovini Bosne in Hercegovine. Ljubljana: Znanstveno in publicistično središče.

- - -. 2002. In hoc signo vinces: verski simbolizem v vojnah na Balkanu 1991-1995. Časopis za kritiko znanosti 30, 193-206.

Vrcan, Srdjan. 1994. La guerra nell'ex Jugoslavia: il coinvolgimento delle religioni. V: Martini, Luciano, ur. Mare di guerra, mare di religioni ECP, 148-177. Firence. 